\title{
15. POLLEN ANALYSIS OF SELECTED SAMPLES FROM DEEP SEA DRILLING PROJECT LEG 63 ${ }^{1}$
}

\author{
Linda E. Heusser, Lamont-Doherty Geological Observatory of Columbia University, Palisades, New York
}

\section{INTRODUCTION}

Marine sediments on continental margins contain varying proportions of marine and terrestrial components. On the slope and rise of several ocean margins, pollen and spores of vascular plants from adjacent continents form an important component of present and past sedimentary records (Heusser, 1978). Brought to the offshore environment primarily by streams, pollen in marine sediments reflects the composition of vegetation in coastal drainage basins, as well as the effects of fluviomarine sedimentation (Cross, Thompson, and Zaitzeff, 1966; Stanley, 1969).

The basic distribution patterns of present vegetation of the Pacific coast of North America are controlled by climate (Wolfe, 1979). The maritime climate of coastal California is determined largely by the zonal circulation over the Pacific Ocean and the northwest-southeasttrending Coast Ranges (Major, 1977). The Mediterranean-type climate of cismontane southern Californialong, warm, dry summers with mild, wet winters-is moderated by coastal fog and characterized by relatively small annual changes in temperature and precipitation. In the Santa Barbara region, for example, rainfall averages 300 to $500 \mathrm{~mm} / \mathrm{yr}$ and annual temperature ranges from $11^{\circ} \mathrm{C}$ to $20^{\circ} \mathrm{C}$ (Elford, 1974).

Coastal vegetation-salt marsh and sagebrush-is composed of broad-leaved sclerophylls and herbs. Characteristic genera are Atriplex (saltbush), Salicornia (glasswort), and Artemisia (sagebrush). Chaparral consisting of woody shrubs such as Cercocarpus (mountain mahogany), Adenostoma (chamise), and Rhus (sumac) is best developed at elevations up to 300 meters. At higher elevations with increased rainfall, woodland of southern oak forest occurs; above 1,500 meters, mixed hardwood forest with coniferous vegetation including species of Pinus (pine) appears (Munz, 1974). Areas south of $33^{\circ} \mathrm{N}$ latitude coastal California and Baja California, Mexico, have a variant of hot-desert-type climate; however, desert vegetation typified by Larrea divaricata (creosote bush) is not dominant until about $30^{\circ} \mathrm{N}$ latitude (Major, 1977; Leopold, 1950). As in cismontane California to the north, coastal strand vegetation and chaparral are replaced by pine-oak forest at higher elevations. On the semi-arid southernmost tip of Baja California, tropical deciduous forest is present in which species of Bursera (elephant tree) are locally common.

\footnotetext{
${ }^{1}$ Initial Reports of the Deep Sea Drilling Project, Volume 63.
}

The principal plant communities of coastal California are broadly reflected in continental and marine pollen records (Adam et al., 1979; Heusser, 1978). Although little quantitative data are available on the relation between existing vegetation and pollen rain in coastal California, qualitative comparison of pollen surface data and vegetation appears to show reasonably good correlation. At $39^{\circ} \mathrm{N}$ latitude, oak pollen composes $80 \%$ of the pollen rain in oak woodland and about $3 \%$ of the pollen rain in the redwood and northcoast forests to the west (where conifer pollen forms $90 \%$ of the modern pollen data [L. Heusser, unpublished data]). In surface pollen samples from coastal-strand communities in southern California, chenopods dominate the vegetation and pollen rain ( $\mathrm{P}$. Mudie, personal communication, 1975). Unfortunately, pollen from some of the characteristic plants of the regional desert and tropical communities is rare or lacking in the pollen record (Cross, Thompson, and Zaitzeff, 1966). This is largely because of the entomophilous nature of many plants from arid environments, such as desert scrub communities (Leopold, 1967). It is important to note that in coastal California, as in many parts of the world, it is difficult to correlate pollen and vegetation data precisely due to the problems in identifying many pollen taxa beyond broad taxonomic levels. Work on the northwest coast of North America, however, has shown that it is possible to relate quantitatively major plant and pollen assemblages (C. J. Heusser et al., 1979).

In addition to those factors affecting pollen in terrestrial environments, marine pollen assemblages are subject to the differential effects of fluviomarine sedimentation. Seaward, on the continental slope and rise, pine increases in marine pollen assemblages, probably reflecting the relative hydrodynamic efficiency of pine pollen grains, although some differential resistance to destruction may be involved (Heusser and Balsam, 1977).

\section{RESULTS}

This study represents a reconnaissance of pollen and spores in selected cores from DSDP Leg 63 sites off California and Mexico (Fig. 1, Table 1). Also shown in Figure 1 and identified in Table 1 are the localities of piston cores tops used to establish the present distribution of pollen in marine surface sediments in the area.

Pollen was concentrated from 6 to $7 \mathrm{~cm}^{3}$ wet sediment by using microscreens in conjunction with sodium pyrophosphate deflocculation of clay-sized particles followed by standard treatment with $\mathrm{HCl}, \mathrm{HF}$, acetolysis solution, and mild oxidation. Stained with Safranin and mounted in glycerin gelatin, pollen was identified with the aid of regional reference collections. 


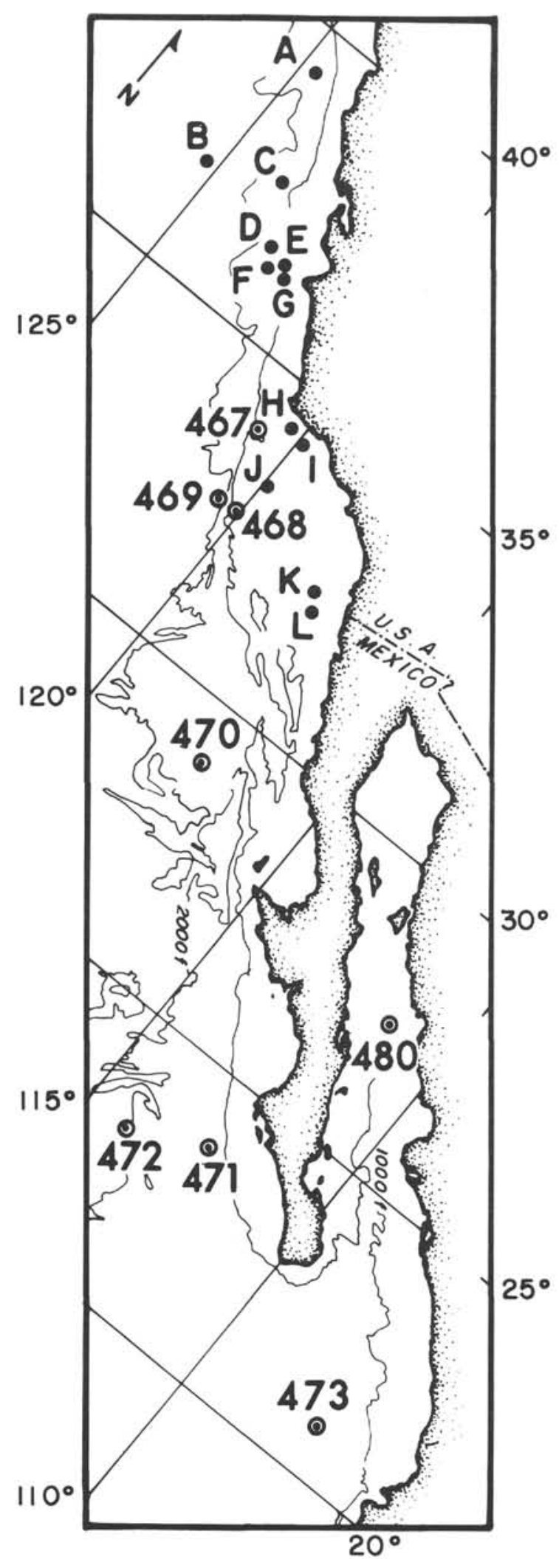

Figure 1. Locations of core sites. (DSDP cores are from Leg 63 Sites $467,468,469,470,471,472,473$, and Leg 64 Site 480 . Piston Core Sites are: A-FAN BG 18; B-FAN HMS 11G; C-FAN BG 16; D-LFGS 2G; E-ANTP 19PG; F-PIF 59G; G-ANTP 20PG; H-Y73 1 1; I-Y73 10117 ; J-AHF 10614; K-MEN 1G; L-M4 $706 \mathrm{P}$; Depth contours are in fathoms.)
Table 1. Core locations and depths.

\begin{tabular}{llllc}
\hline Site & \multicolumn{1}{c}{ Core } & $\begin{array}{c}\text { Latitude } \\
\text { (north) }\end{array}$ & $\begin{array}{c}\text { Longitude } \\
\text { (west) }\end{array}$ & $\begin{array}{c}\text { Sub-bottom } \\
\text { Depth } \\
\text { (m) }\end{array}$ \\
\hline A & FAN BG 18 & $39^{\circ} 14^{\prime}$ & $125^{\circ} 03^{\prime}$ & 3200 \\
B & FAN HMS 11G & $37^{\circ} 01^{\prime}$ & $125^{\circ} 21^{\prime}$ & 4350 \\
C & FAN BG 16 & $37^{\circ} 11^{\prime}$ & $124^{\circ} 34^{\prime}$ & 3850 \\
D & LFGS 2G & $36^{\circ} 40^{\prime}$ & $123^{\circ} 16^{\prime}$ & 3328 \\
E & ANTP 19PG & $36^{\circ} 29^{\prime}$ & $122^{\circ} 49^{\prime}$ & 3019 \\
F & PIF 59G & $36^{\circ} 25^{\prime}$ & $122^{\circ} 48^{\prime}$ & 2935 \\
G & ANTP 20PG & $36^{\circ} 26^{\prime}$ & $123^{\circ} 06^{\prime}$ & 3229 \\
H & Y73 1 1 & $34^{\circ} 11^{\prime}$ & $120^{\circ} 06^{\prime}$ & 575 \\
I & Y71 10 117 & $34^{\circ} 16^{\prime}$ & $120^{\circ} 04^{\prime}$ & 570 \\
J & AHF 10614 & $32^{\circ} 50^{\prime}$ & $119^{\circ} 19^{\prime}$ & 1200 \\
K & MEN 1G & $32^{\circ} 36^{\prime}$ & $118^{\circ} 07^{\prime}$ & 1920 \\
L & M4-70-6P & $32^{\circ} 11^{\prime}$ & $117^{\circ} 43^{\prime}$ & 1793 \\
467 & $467-2$ & $33^{\circ} 51^{\prime}$ & $120^{\circ} 46^{\prime}$ & 1042 \\
468 & $468-2$ & $32^{\circ} 37^{\prime}$ & $120^{\circ} 07^{\prime}$ & 1849 \\
468 & $468 \mathrm{~B}-1$ & $32^{\circ} 38^{\prime}$ & $120^{\circ} 07^{\prime}$ & 1737 \\
469 & $469-1$ & $32^{\circ} 37^{\prime}$ & $120^{\circ} 33^{\prime}$ & 3790 \\
470 & $470-1$ & $28^{\circ} 55^{\prime}$ & $117^{\circ} 31^{\prime}$ & 3549 \\
470 & $470 \mathrm{~A}-1$ & $28^{\circ} 55^{\prime}$ & $117^{\circ} 31^{\prime}$ & 3549 \\
471 & $471-1$ & $23^{\circ} 29^{\prime}$ & $112^{\circ} 30^{\prime}$ & 3101 \\
472 & $472-1$ & $23^{\circ} 01^{\prime}$ & $114^{\circ} 00^{\prime}$ & 3831 \\
473 & $473-2$ & $20^{\circ} 58^{\prime}$ & $107^{\circ} 04^{\prime}$ & 3249 \\
480 & $480-1$ & $27^{\circ} 54^{\prime}$ & $111^{\circ} 39^{\prime}$ & 655 \\
\hline & & & & \\
\hline
\end{tabular}

Note: The first 12 are from Piston Core Sites A-L; the others are from DSDP Leg 63 (and the last [480] is from DSDP Leg 64).

From each hole drilled on Leg 63, the youngest samples available were processed for pollen. They were: Samples 63-467-2-1, 90-94 cm; 63-468-1-1, 138-140 cm; 63-468B-1-1, 40-42 cm; 63-469-1-1, 57-59 cm; 63-470-1$1,88-92 \mathrm{~cm} ; 63-470 \mathrm{~A}-1-1,110-115 \mathrm{~cm} ; 63-471-1-1,96-$ $100 \mathrm{~cm}$; 63-472-1-2, 90-95 cm; and 63-473-2-1, 110-115 $\mathrm{cm}$. In addition, 75 samples were processed from Cores 2 through 110 from Hole 467. All samples processed from Leg 63 contained pollen; quantities ranged from 2 pollen grains $/ \mathrm{cm}^{3}$ to over 8,000 pollen grains $/ \mathrm{cm}^{3}$. The uppermost sample from Cores 467-2, 468-1, 468B-1, 469-1, and 473-2 contained at least 1,000 pollen grains/ $\mathrm{cm}^{3}$; samples from Cores 470-1, 470A-1, 471-1, and 472-1 contained less than 600 grains $/ \mathrm{cm}^{3}$.

Figure 2 illustrates the percentages of the major pollen groups occurring in Leg 63 samples (in which 100 or more pollen grains were counted). Pine (Pinus) and oak (Quercus) are the most abundant arboreal types, and composites (members of the Compositae family) and chenopods (members of the Chenopodiaceae and probably including members of the Amaranthaceae) dominate the nonarboreal pollen. Not shown in the pollen diagram are infrequently occurring types-Ephedra, Alnus, spores of terrestrial plants, and palynomorphs (such as microforaminifers and dinoflagellates; dinoflagellates, in fact, form up to $80 \%$ of the total pollen + spores + palynomorphs). Pollen and spores that could be positively identified as re-worked, either by morphology or by stain acceptance, were never abundant.

Figure 2 also shows the percentages of these same major pollen groups in marine surface samples off California (Piston Core Sites A-L) and Mexico (DSDP Site 480 ). Note that the relative abundance of pine 

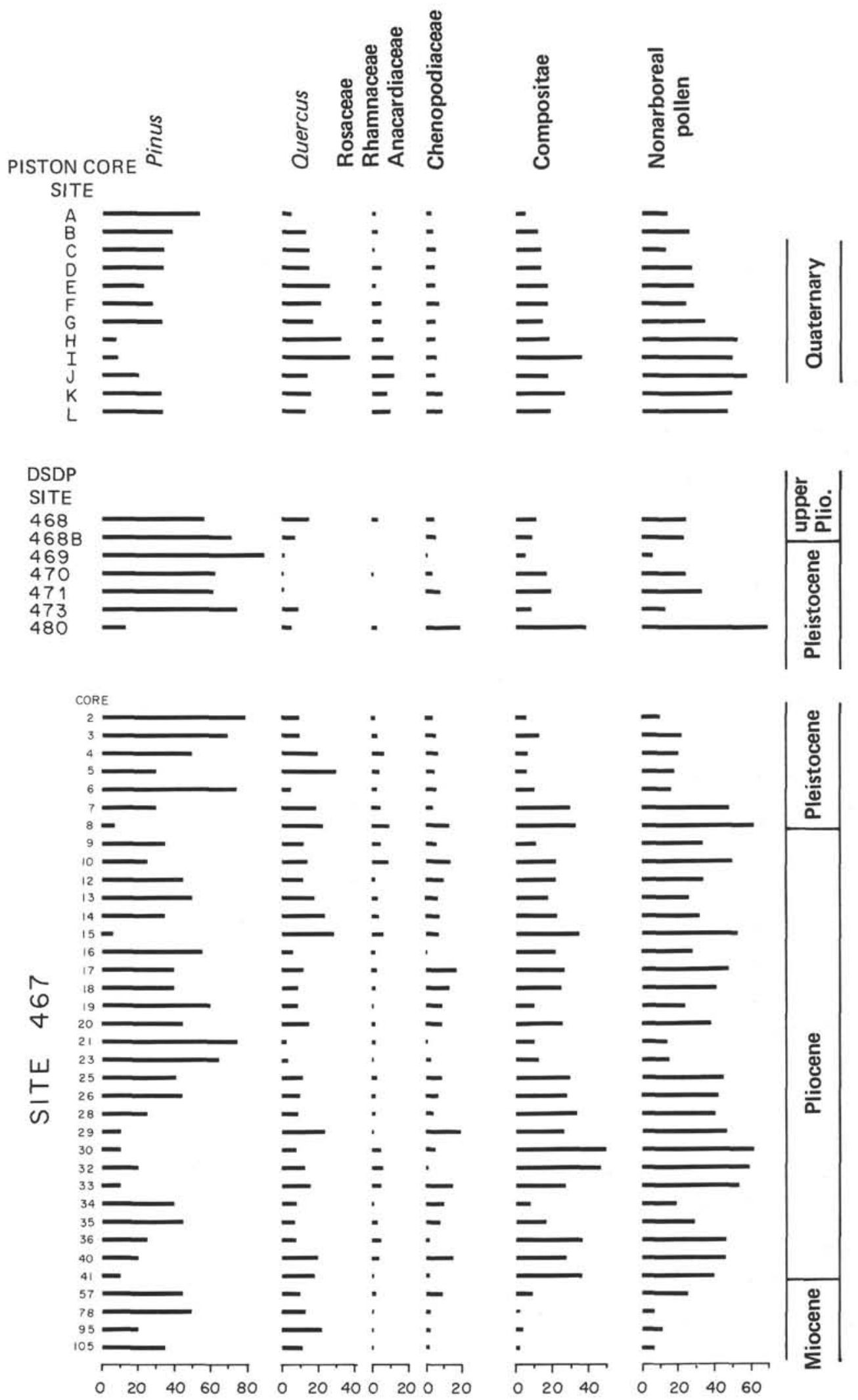

Figure 2. Relative abundance of selected components of pollen from DSDP Sites 467, 468, 469, 470, 471, 473, and 480 and Piston Core Sites A through L. (Age assignments for Leg 63 DSDP cores are based on marine microfossil studies in this volume. Age assignments for Piston Cores A-L and DSDP Site 480 are based on pollen data.) 
pollen decreases southward from Piston Core Sites A to I and DSDP Site 64-480. The rise of pine pollen at Sites $\mathrm{J}, \mathrm{K}$, and $\mathrm{L}$ illustrates the increase in the relative abundance of pine seawards, mentioned previously. Highest proportions of oak pollen are found off central California (Sites E-I). Nonarboreal pollen, primarily that of composites, forms over $50 \%$ of pollen in modern marine sediments off southern California and Mexico (Sites H-L, DSDP Site 64-480). Greater prominence of members of the Rosaceae (rose), Rhamnaceae (buckthorn) and Anacardiaceae (sumac) families found in chaparral vegetation occurs in surface sediments off southern California.

Pollen in cores frem Hole 467 (Fig. 2) shows large fluctuations in the relative abundance of pine (10-80\%), composites (2-50\%), and total nonarboreal pollen (6$60 \%$ ). Little apparent difference is shown by the percentages of the major pollen taxa between Miocene, Pliocene, and Pleistocene samples. Representatives of pollen types not found in present vegetation occur occasionally in lower Pliocene samples, for example, Ilex, Ulmus, Tilia, and Pterocarya. And along with Liquidambar, these types are found in Miocene samples. Artemisia was first observed in Core 467-42.

\section{DISCUSSION}

Cores from the outer California Continental Borderland (Holes 467, 468, and 469) and from the mouth of the Gulf of California (Hole 473) contain relatively large amounts of pollen, quantities comparable with concentration of pollen in marine surface samples in area (Cross, Thompson, and Zaitzeff, 1966; Heusser and Balsam, 1977). The scarcity of pollen in holes off Baja California, Mexico (with its desert-vegetation environments) is probably because of the relative lack of pollen dispersal by the plants of this area and the absence of permanent drainage to transport the pollen to the marine environment. Similar reasons were suggested to account for differences in the concentration of pollen in sediments of the Mediterranean Sea (Koroneva, 1971). As in surface sediments of the continental margin of the Pacific Ocean north of the area drilled during Leg 63, high pollen content appears correlative with high organic content in Hole 467, suggesting similar sedimentary controls.

The reconnaissance nature of the pollen analyses from Hole 467 precludes any definite stratigraphic or climatic inferences from the cores. The Miocene through Pleistocene pollen assemblages from Hole 467 at San Miquel Gap have an overall similarity to pollen assemblages found in marine surface samples from offshore northern California to the Gulf of California. This suggests that conditions in the source areas of the pollen-the coastal drainage basins to the east-did not vary greatly from present conditions, which range from Mediterranean California to desert climates. The initial pollen data from Hole 467 can be interpreted as indicating that climate on the coast adjacent to the northern California Borderland was warmer and drier in the Pliocene than in the Pleistocene; however, high percentages of composite and chenopod pollen in Pleistocene samples do suggest a summer-dry climate through the past few million years. This agrees with geologic, pedologic, and paleobotanic evidence that late Quaternary climate changes did not basically alter the semi-arid climate of coastal California (Johnson, 1977). Pollen analyses of samples from DSDP Hole $434\left(39^{\circ} 28^{\prime} \mathrm{N}, 127^{\circ} 16^{\prime} \mathrm{W}\right)$ to the north of Hole 63-467 suggest similar climatic changes: Pliocene samples contain lower percentages of conifers such as spruce (Picea), and western hemlock (Tsuga heterophylla) than do Pleistocene samples (L. Heusser, unpublished data). The apparent increase of composites at the end of the Miocene may also in part reflect evolutionary expansion of the Compositae family, which first appeared in the lower Miocene (Leopold, 1969).

Miocene and Pliocene pollen data from Hole 467 are generally similar to pollen data from approximately isochronous units in the Los Angeles Basin, California (Martin and Gray, 1962). Like the offshore core, the marine sediments in the Wilmington, California core are dominated by pine. The continual presence of pollen from herbs and shrubs such as chenopods, composites, and Ephedra is interpreted as indicative of the presence of arid plant communities in the coastal California area since the late Miocene.

Evidence from continental sediments bearing on the development and relationships of California flora during the Miocene, Pliocene, and Pleistocene suggests that summer-dry climates are a post-Eocene development in southern California (Munz, 1974; Raven and Axelrod, 1977). By early Miocene, sclerophyllous vegetation covered much of southern California, and the midPliocene appears to have been the dryest part of the California Tertiary (Axelrod, 1978). The last exotic broad-leaved deciduous trees are found in the upper Pliocene. Near Santa Rosa, California, late Pliocene coastal forest of spruce, fir (Abies), western hemlock, and Sequoia also contains species of Ulmus and Ilex (Axelrod, 1944). Vegetation during the Pleistocene is characterized more by geographic displacements than by taxonomic change. The pollen data from Hole $467 \mathrm{fit}$ within the framework of the paleobotanical evidence.

\section{CONCLUSION}

Variations in marine biota off California reflect evolutionary and climatic change in the marine environment since the Tertiary. Variations in the continental biota of California reflect evolutionary and climatic changes in the environment of the adjacent continent during the same time interval. Palynological reconnaissance of sediments from Hole 63-467 suggests that further detailed pollen analyses should produce a relatively continuous record of the development of the continental coastal biota and climates during the late Cenozoic, which would be directly correlative with the marine record.

\section{ACKNOWLEDGMENTS}

The support of NSF Grant DEB 79-12231 is gratefully acknowledged, as is the help of the reviewers, C. Sancetta and C. Heusser. 


\section{REFERENCES}

Adam, D. P., Byrne, R., and Luther, E., 1979. A late Pleistocene and Holocene pollen record from Laguna de las Trancas, northern coastal Santa Cruz County, California. Geol. Surv. Open File Rep. 79-545: Washington (U.S. Govt. Printing Office).

Axelrod, D. I., 1944. The Sonoma flora (California). Carnegie Inst. Washington Publ., 553:167-206.

1978. The origin of coastal sage vegetation, Alta and Baja California. Am. J. Bot., 65:1117-1131.

Cross, A. T., Thompson, G. G., and Zaitzeff, J. B., 1966. Source and distribution of palynomorphs in bottom sediments, southern part of Gulf of California. Mar. Geol., 4:467-524.

Elford, C. R., 1974. The climate of California. In van der Leeden, F., Troise, F. L. (Eds.), Climates of the States, II: Port Washington, New York (Water Information Center), pp. 538-594.

Heusser, C. J., Heusser, L. E., and Streeter, S. S., 1979. Pollen spectra from the northwest coast of North America correlated with temperature and precipitation: application to Quaternary pollen. Geol. Soc. Am. Abstract with Programs, 11:443. (Abstract)

Heusser, L. E., 1978. Spores and pollen in the marine realm. In Haq, B. U., and Boersma, A. (Eds.), Introduction to Marine Micropaleontology: New York (Elsevier), pp. 327-340.

Heusser, L. E., and Balsam, W. L., 1977. Pollen distribution in the northeast Pacific Ocean. Quaternary Res., 7:45-62.

Johnson, D. L., 1977. The late Quaternary climate of coastal California: evidence for an Ice Age refugium. Quaternary Res., 8:154179.
Koroneva, E. V., 1971. Spores and pollen in Mediterranean bottom sediments. In Funnel, B. M., and Reidel, W. B. (Eds.), The Micropaleontology of Oceans: Cambridge (University Press), pp. 361371.

Leopold, A. S., 1950. Vegetation zones of Mexico. Ecology, 31:507517.

Leopold, E. B., 1967. Summary of palynological data from Searles Lake. Pleistocene Geology and Palynology Searles Valley, California: (Friends of the Pleistocene, Pacific Coast Section), pp. $52-66$.

1969. Late Cenozoic palynology. In Tschudy, R. H., and Scott, R. A. (Eds.), Aspects of Palynology: New York (Wiley), pp. 377-438.

Major, J., 1977. California climate in relation to vegetation. In Barbour, M. G., and Major, J. (Eds.), Terrestrial Vegetation of California: New York (Wiley), pp. 11-74.

Martin, P. S., and Gray, J., 1962. Pollen analysis and the Cenozoic. Science, 137:103-111.

Munz, P. A., 1974. A Flora of Southern California: Berkeley (University of California Press).

Raven, P. H., and Axelrod, D. I., 1977. Origin and relationships of the California flora. University California Publ. Botany, 72: $1-134$.

Stanley, E. A., 1969. Marine palynology. Oceanogr. Mar. Biol. Annu. Rev., 7:277-292.

Wolfe, J. A., 1979. Temperature parameters of humid to mesic forests of eastern Asia and relation to forests of other regions of the northern hemisphere and Australasia. Geol. Surv. Prof. Paper 1106: Washington (U.S. Govt. Printing Office). 